\title{
Effect of Financial Ratios on Stock Returns with Earning Per Share as Moderating Variable in Banking Companies on the Indonesia Stock Exchange (2012-2017 Period)
}

\author{
Sahat M N Siahaan ${ }^{1}$, Isfenti Sadalia ${ }^{2}$, Amlys Syahputra Silalahi ${ }^{3}$ \\ ${ }^{1,2,3}$ Universitas Sumatera Utara, Indonesia \\ Corresponding Author: Sahat M N Siahaan
}

\section{ABSTRACT}

The purpose of this study is to analyze the effect of financial ratios on stock returns with earning per share as moderating variable in Banking Companies on the Indonesia Stock Exchange (2012-2017 period). This research is a comparative causal research, which is to analyze the causal relationship between two or more variables. The seven companies are Bank Mandiri (Persero) Tbk (BMRI), Bank Central Asia Tbk (BBCA), BANK Rakyat Indonesia (Persero) Tbk (BBRI), Bank Bumi Arta Tbk (BNBA), Bank Negara Indonesia (Persero) Tbk (BBNI), Bank Tabungan Negara (Persero) Tbk (BBTN) dan Bank Mega Tbk (MEGA), so that with a 6-year financial report, there are $(7 \times 6)=42$ research samples. The data analysis method used in testing the hypothesis in this study is multiple linear regression analysis and moderated variable regression analysis with the absolute difference value test method. Based on the results of the study, it shows that the current ratio (CR) has a positive and significant effect on stock returns at Banking Companies on the Indonesia Stock Exchange. Total asset turnover (TAT) has a positive and significant effect on stock returns in Banking Companies on the Indonesia Stock Exchange. Debt to equity ratio (DER) has a negative and significant effect on stock returns of Banking Companies on the Indonesia Stock Exchange. Return on investment (ROI) has a positive and significant effect on stock returns of Banking Companies on the Indonesia Stock Exchange. Earning per share (EPS) is not able to significantly moderate the relationship between CR and stock returns.
\end{abstract}

EPS is able to significantly moderate the relationship between TAT and stock returns. EPS is able to significantly moderate the relationship between DER and stock returns. EPS is not able to significantly moderate the relationship between ROI and stock returns.

Keywords: Financial Ratios, Stock Returns, Earning Per Share

\section{INTRODUCTION}

According to Tandelilin (2019:26), "the capital market is a market for buying and selling securities which generally have a lifespan of more than one year, such as stocks and bonds". The market aims to bring together the owners of capital (investors) with issuers (Hermuningsih, 2012:2). The capital market has two functions, namely the economic function and the financial function. The economic function of the capital market is to channel funds from investors to companies, while the financial function is to reward investors for their investment results in the form of profits to maximize wealth. "Instruments offered through the capital market are instruments in the form of securities or securities. The instruments are divided into two major groups, namely ownership instruments (equity), such as stocks and debt instruments such as corporate bonds" (Darmadji and Fakhruddin, 2011:2).

"Investors invest their funds by buying shares in a company listed on the 
Indonesia Stock Exchange to obtain a return or income from their investment" (Kumala, 2013). "This investment has various kinds of risks and uncertainties that are difficult for investors to predict because of fluctuations in stock prices that go up and down quickly" (Habib, 2016). This causes investors to be careful in deciding which stock investment to make. In the world of investment, investors have the main goal to get a return. The return received by the company's shareholders always fluctuates from year to year, so investors need information about the company from the financial statements. The published financial statements can provide information about the company's performance, which can be analyzed using the financial ratios contained in the financial statements.

Based on the data, it can be seen that there have been fluctuations in stock returns from several banking companies listed on the Indonesia Stock Exchange for the period 2012-2017, namely there is an up and down graph of stock returns that describes the company's performance in each period from year to year, there is information that can be obtained, if it rises then the value of the stock return is positive it will make a profit and if it goes down the value is negative it will suffer a loss.

Based on the data, it can be seen that there are fluctuations in the current ratio (CR), total asset turnover (TAT), debt to equity ratio (DER) and return on investment (ROI) from several banking companies listed on the Indonesia Stock Exchange for the period 2012-2017, namely the graph up and down from CR, TAT, DER and ROI which describe the company's financial ratios every year.

A company can experience fluctuating returns at any time because it is influenced by macroeconomic and microeconomic factors. "Macroeconomic factors are factors that are outside the company, namely inflation, interest rates, foreign exchange rates, and economic growth, while microeconomic factors or also called company fundamental factors are factors that are inside the company itself and can be seen through the company's financial performance" (Alwi, 2010:87).

The liquidity ratio in this study is proxied by $\mathrm{CR}$, which is a way to test the level of protection obtained by short-term lenders provided by the company to fund the company's operational activities. The effect of CR on stock returns is that if the $\mathrm{CR}$ is low, it will cause a decrease in stock returns, and if the $\mathrm{CR}$ is too high it is considered unfavorable, because under certain conditions it shows a lot of idle company funds (little activity) which can ultimately reduce the company's profitability.

TAT is an activity ratio that measures the overall turnover of all assets. This ratio is used quite often because of its comprehensive coverage. Regardless of the type of business, this ratio can describe how well all assets support to obtain sales. TAT is an activity ratio that can cause stock returns to increase.

DER is an attempt to show the relative proportion of lenders to ownership rights, and is used as a measure of the role of debt. The higher the DER indicates the greater the company's dependence on outside parties so that the company's risk level is greater in meeting its debts, namely paying the principal plus the interest. This has an impact on decreasing stock prices and stock returns, so that investors are not responsive to this information in making investment decisions in stocks.

ROI is the quotient between net income and the total investment invested in company assets. ROI is an important financial ratio analysis because it is comprehensive, so ROI is used to assess the level of effectiveness of the company as a whole. Therefore, this ratio compares the profit after interest and tax earned by the company with the amount of assets used to earn that profit. The greater the ROI value, the company's performance increases. Investors will be interested in investing in companies that have increased performance, 
so that the company's stock price will increase.

Good company performance with the monitoring of the company's work assessment, which can be seen from the financial ratios to the returns expected by investors which are higher than when the initial investors invested their funds in the company. Research by Petcharabul and Suppanunta (2014) and Rahman (2014) shows that the activity and market aspects have no significant effect on stock returns, while aspects of capital, liquidity, and profitability have a positive and significant effect on stock returns of banking companies.

Earning per share (EPS) is the level of profit obtained by shareholders in each share owned. EPS is obtained from net income after interest and taxes divided by the number of ordinary shares outstanding. The higher the EPS value will increase the interest of investors to invest. The more the number of investments made, the company will experience an increase in stock prices, and will provide a high level of stock returns.

Prastowo and Juliaty (2008:99) say that "in the capital market EPS shows the amount of profit that is the right of each shareholder".

The EPS ratio can strengthen or weaken the influence of the company's fundamental factors through financial ratios on stock prices. Based on the results of previous studies, it was found that EPS had a positive effect on stock prices. The EPS ratio gives a signal to potential investors about the profitability of each share.

Stock return is the result obtained by investors from investment activities on the purchase of shares. Investors will be happy if they get high returns from time to time. Stock return as an indicator of the company's performance directly to shareholders. The higher the stock return obtained, the investors are happy to invest in the company.

The purpose of this study is to analyze the effect of financial ratios on stock returns with earning per share as moderating variable in Banking Companies on the Indonesia Stock Exchange (20122017 period).

\section{RESEARCH METHODS}

Research on financial ratios to stock returns in banking companies listed on the Indonesia Stock Exchange was carried out starting in December 2017 by collecting data on the Indonesia Stock Exchange through published financial reports. The data collection period is 6 years, namely 2012-2017.

This research is a comparative causal research, which is to analyze the causal relationship between two or more variables (Pandiangan et al., 2018).

The population in this study were all banking companies listed on the Indonesia Stock Exchange from 2012-2017, totaling 45 companies. After the analysis, 7 companies were selected which of course had complete financial statements starting in 2012-2017, which were complete, so that the seven banking companies were used as samples. The seven companies are Bank Mandiri (Persero) Tbk (BMRI), Bank Central Asia Tbk (BBCA), BANK Rakyat Indonesia (Persero) Tbk (BBRI), Bank Bumi Arta Tbk (BNBA), Bank Negara Indonesia (Persero) Tbk (BBNI), Bank Tabungan Negara (Persero) Tbk (BBTN) dan Bank Mega Tbk (MEGA), so that with a 6 -year financial report, there are $(7 \times 6)=42$ research samples.

The data analysis method used in testing the hypothesis in this study is multiple linear regression analysis and moderated variable regression analysis with the absolute difference value test method.

\section{RESULT}

\section{History of Banking Companies on the Indonesia Stock Exchange}

The Indonesia Stock Exchange divides companies' industrial groups based on the sectors they manage, consisting of the agricultural sector, mining sector, basic chemical industry sector, various industrial 
sectors, consumer goods industry sector, property sector, infrastructure sector, financial sector, and trade services sector. investment.

The financial sector is one group of companies that play an active role in the capital market because the financial sector is a supporter of the real sector in the Indonesian economy. The financial sector on the Indonesia Stock Exchange is divided into five sub-sectors consisting of banking, financial institutions, securities companies, insurance companies and others. The banking sub-sector is a company that is currently in great demand by investors because the yield or return on shares to be obtained is promising. Banks are known as financial institutions whose main activity is accepting demand deposits, savings and time deposits. Then the bank is also known as a place to borrow money (credit) for people who need it.

Based on Law No. 7 of 1992 concerning banking states that a bank is "a business entity that collects from the public in the form of deposits and distributes them to the public in order to improve the standard of living of the people". Meanwhile, according to the Law of the Republic of Indonesia Number 10 of 1998 dated November 10, 1998 concerning banking, what is meant by a bank is "a business entity that collects funds from the public in the form of savings and distributes them to the public in the form of credit and or other forms in order to improve the quality of life of the community, the lives of many people".

Based on Law No. 10 of 1998, the function of banks in Indonesia is to collect funds from the public. Banks are in charge of securing savings and time deposits as well as deposits in checking accounts or checking accounts. As a distributor of funds or credit providers, banks provide credit to people in need, especially for productive businesses.

The following is a company profile in the sub-sector of banking companies listed on the Indonesia Stock Exchange for the period $2012-2017$ as follows:

\section{PT Bank Mandiri (Persero) Tbk}

Bank Mandiri was established on October 2, 1998, as part of the banking restructuring program implemented by the Indonesian government. In July 1999, four state banks, namely Bank Bumi Daya, Bank Dagang Negara, Bank Exim and Bapindo were merged into Bank Mandiri.

\section{PT Bank Central Asia Tbk}

Bank Central Asia is the largest private bank in Indonesia. The bank was established on February 21, 1957. The initial public offering took place in 2000 , by selling $22.55 \%$ of the shares derived from the divestment of BPPN. After the initial public offering, BPPN still controls $70.30 \%$ of all BCA shares. The second share offering was held in June and July 2001 with BPPN divesting another $10 \%$ of its BCA shares through a strategic private placement tender. Farindo Investment, Ltd., based in Mauritius, won the tender.

\section{PT Bank Rakyat Indonesia (Persero) Tbk}

Bank BRI was founded in Purwokerto, Central Java by Raden Aria Wirjaamadja which was established on December 16, 1895, BRI is the first state bank in Indonesia. PT BRI (Persero) Tbk is based on small community services that has remained consistent until now, namely with a focus on providing credit facilities to small entrepreneurs.

\section{PT Bank Artha Graha Internasional Tbk}

Starting as a Non-Bank Financial Institution named PT Inter-Pacific Financial Corporation, established on September 7, 1973 on February 24, 1993, changed its status and function to become a joint venture bank conducting commercial bank activities under the name PT Inter-Pacific Bank. Five years later, Bank Indonesia gave permission to take over the ownership of the shares. 


\section{PT Bank Negara Indonesia (Persero) Tbk}

Bank BNI Established in 1946, BNI was the first bank to be established and owned by the Indonesian government. Due to the addition of capital in 1955, the status of Bank Negara Indonesia was changed to a state-owned commercial bank. This change underlies better services for the national business sector. Bank Negara Indonesia 1946 was officially used starting at the end of 1968. This change made Bank Negara Indonesia better known as BNI 46.

\section{PT Bank Tabungan Negara (Persero) Tbk}

PT Bank Tabungan Negara (Persero) Tbk or commonly known as Bank BTN is one of the state-owned companies engaged in financial services. The Bank Tabungan Negara as a state-owned bank is stipulated by Law No. 20 of 1968 dated December 19, 1968. PT Bank Tabungan Negara (Persero) Tbk. or known as Bank BTN is one of the financial institutions that also distribute funds in the form of credit. Bank BTN has a very long history in the banking industry in Indonesia. Bank BTN has been established since 1897 under the name Postpaarbank. In the era of independence, in 1950 to be exact, the Government of the Republic of Indonesia changed the name Postpaarbank to Bank Tabungan Pos and then changed its name again to Bank Tabungan Negara in 1963. In 1974, the Company was appointed by the Government as the only institution that distributes home ownership loans (KPR). for the lower middle class, in line with the Government's program which is promoting a housing program for the people. The Company listed its initial shares on December 17, 2009 on the Indonesia Stock Exchange, and became the first bank in Indonesia to perform asset securitization through the recording of collective investment contracts-asset backed securities (KIK-EBA) transactions. As a bank that focuses on housing finance, the Company wishes to assist the Indonesian people in realizing their dream of owning a dream home. This desire is demonstrated by its consistency for more than six decades, in providing a variety of products and services in the housing sector, especially through mortgages, both mortgages and mortgages. Subsidies for the lower middle segment and non-subsidized mortgages for the upper middle segment. As a bank that focuses on housing finance, the Company has also succeeded in increasing its position to become the 7th largest bank in Indonesia in terms of assets and lending.

\section{PT Bank Mega Tbk}

Bank Mega Starting from a familyowned business called PT. Bank Karman which was founded in 1969 and domiciled in Surabaya, Along with the development of PT. Mega Bank in 1996 was taken over by PARA GROUP (PT. Para Global Investindo and PT. Para Rekan Investama) and in 2000 the name was changed from PT. Mega Bank became PT. Mega Bank. In order to strengthen the capital structure, in the same year PT. Bank Mega conducts initial public offering and is listed on the BEJ and BES. Thus, some of the shares of PT. Bank Mega is owned by the public

\section{Banking Subsector Company Activities}

In general, the activities of the banking sub-sector companies are as follows:

\section{Money Creation}

The money created by commercial banks is demand deposit, which is a means of payment through a book-entry mechanism (clearing). The ability of commercial banks to create demand deposits causes their position and function in the implementation of monetary policy. The central bank can reduce or increase the money supply by influencing the ability of commercial banks to create demand deposits. For example, changing the reserve requirement ratio will affect the ability of commercial banks to create demand deposits. 


\section{Support Smooth Payment Mechanism}

Another very important activity is to support the smooth running of the payment mechanism. This is possible because one of the services offered by commercial banks is services related to payment mechanisms. Some of the services that are very well known are clearing, money transfers, accepting deposits, providing payment facilities by cash, credit, easy and convenient payment facilities such as plastic cards and electronic payment systems such as debit cards, credit cards, e-toll cards, SMS banking, mobile banking, internet banking, and the latest services for smart phone users. BlackBerry banking services with the services mentioned above will make it easier for customers to obtain information from banks related to balance information, account mutations, exchange rate info, savings interest rate info, rupiah deposits, foreign exchange deposits, change PIN, activation and others.

\section{Fundraising Deposits}

The funds that are collected the most by commercial banks are savings funds. In Indonesia, deposit funds consist of demand deposits, time deposits, certificates of deposit, savings, and or other equivalent forms. Savings funds that have been collected and distributed to parties in need, mainly through lending.

\section{Supports Smooth International Transactions}

Commercial banks are also needed to facilitate and/or expedite international transactions, both goods/services transactions and capital transactions. Transaction difficulties between two parties from different countries always arise due to differences in geography, distance, culture, and the monetary system of each country. The presence of commercial banks operating on an international scale will facilitate the settlement of these transactions. With the existence of commercial banks, the interests of parties conducting international transactions can be handled more easily, quickly and cheaply.

\section{Storage of valuables and securities}

Storage of valuables is the earliest service offered by commercial banks. People can store their valuables such as jewelry, money, and diplomas in boxes that are intentionally provided by commercial banks for rent (safe deposit boxes). Rapid economic development causes banks to expand services by storing securities.

\section{Activities in the Capital Market}

The activities that can be carried out by commercial banks in the capital market are: underwriters, guarantors, trustees and dealers. Commercial banks can also act as founders of pension funds and administrators of pension funds in accordance with the provisions of the applicable pension fund laws and regulations.

\section{Variable Description}

Description of each variable for current ratio (CR), total asset turnover (TAT), debt to equity ratio (DER), return on investment (ROI), earning per share (EPS), and stock returns can be seen in Table 1.

Table 1. Average Current Ratio, Total Assets Turnover, Debt to Equity Ratio, Return on Investment and Stock Returns

\begin{tabular}{|l|l|l|l|l|l|l|}
\hline Year & CR & TAT & DER & ROI & EPS & $\begin{array}{l}\text { Stock } \\
\text { Returns }\end{array}$ \\
\hline 2012 & 1.04 & 9.16 & 9.02 & 2.00 & 262.52 & 0.02 \\
\hline 2013 & 1.25 & 11.86 & 7.38 & 2.42 & 231.66 & 0.06 \\
\hline 2014 & 1.29 & 12.43 & 8.35 & 2.97 & 227.67 & 0.06 \\
\hline 2015 & 1.37 & 15.61 & 6.33 & 3.96 & 234.22 & 0.10 \\
\hline 2016 & 1.26 & 15.33 & 8.89 & 3.14 & 235.49 & 0.09 \\
\hline 2017 & 1.34 & 16.28 & 6.56 & 4.16 & 236.76 & 0.12 \\
\hline \multicolumn{6}{|c|}{ Source: Research Results } \\
\hline
\end{tabular}

Table 1 shows that the current ratio (CA) has increased and decreased from 2012 to 2017 in a fluctuating manner. The highest CA occurred in 2015. This CA also shows the efficiency of the banking company's operating cycle. The higher the current ratio, the more liquid the company is. Basically, this acceptable CA varies from industry to industry. For most industries, a current ratio of 2 times is considered acceptable or "acceptable". A low value in 
the current ratio (a value that is less than 1 time) indicates that the company may have difficulty meeting its current obligations. However, investors or potential creditors must also pay attention to the company's operating cash flow in order to better understand the company's liquidity level.

If the company's CA is low, investors or potential creditors can assess the financial health of the company concerned with the operating cash flow condition of the company. If the current ratio is too high (a value that is more than 2 times), then the company may not use its current assets or short-term financing facilities efficiently. It also indicates that there may be problems in working capital management. However, for creditors, a high current ratio is better than a low current ratio, because a high current ratio means that companies tend to be more likely to meet debt obligations that mature in the next 12 months.

Table 1 shows that total asset turnover (TAT) has increased from 20122017. TAT is also a ratio that shows the level of efficiency in the use of the company's overall assets in generating a certain sales volume. So the greater the total assets turnover, the better, which means that the assets can be turned around more quickly and make a profit and show the more efficient use of the overall assets in generating sales.

Table 1 shows that the debt to equity ratio (DER) has fluctuated and decreased from 2012-2017. The greater the DER of a company indicates that the company uses large debt as a source of company funding, thus causing the company's risk to be higher.

Table 1 shows that the return on investment (ROI) has increased from 20122017. The greater the value of the ROI ratio, the greater the funds that can be returned from equity into profit. This means that the greater the net profit obtained from own capital. High ROI shows the position of the company's capital owners is getting stronger.
Table 1 also shows that stock returns have fluctuated and decreased from 20122017. Stock return is the rate of return of profits enjoyed by investors on an investment they make. Without the benefits that can be enjoyed from an investment activity, of course, investors will not want to bother making investments, which in the end will have no results. Stock prices also reflect the value of a company. If the company achieves good performance, then the company's shares will be in great demand by investors. The good achievements achieved by the company can be seen in the financial statements that have been published by the issuer company.

Table 1 also shows that earnings per share (EPS) fluctuated between 2012-2017. Earnings per share is a very useful measure of profitability and when compared to earnings per share in similar companies, earnings per share will provide a very clear picture of the strength of profitability between the company concerned and the comparison company. Please note that the comparison company must be a company operating in the same type of industry. This Earning per Share, if calculated over several years, will show whether the company's profitability is getting better or worse. Investors will usually invest their funds in companies whose earnings per share continue to increase. EPS growth is an important measure of a company's performance because it shows how much money a company makes for its shareholders. Not only because of changes in profits but also after all the impact of issuing new shares.

EPS is very important in the company's financial statements. EPS provides information to outside parties (external) how far the company's ability to generate profits for each outstanding sheet. As an indicator of past success and future expectations, EPS provides an important picture of that success. However, EPS is not the only means of assessing the company's success. This tool still has to be combined with other tools and interpreted further. 
In general, in investing, investors expect the benefits to be generated in the form of EPS. While the amount of EPS distributed to investors depends on the company's policy in terms of dividend payments. EPS can show the level of welfare of the company, so if the EPS distributed to investors is high, it indicates that the company is able to provide a good level of welfare to shareholders, while EPS that is distributed is low, it indicates that the company failed to provide benefits as expected by shareholders.

\section{Multiple Linear Regression Analysis}

The results of the multiple linear regression test with the moderating variable (absolute difference value test method) used to answer can be seen in Table 2 .

Table 2. Multiple Linear Regression Test Results

\begin{tabular}{|c|c|c|c|c|c|c|}
\hline \multicolumn{7}{|c|}{ Coefficients $^{\mathrm{a}}$} \\
\hline \multirow{2}{*}{\multicolumn{2}{|c|}{ Model }} & \multicolumn{2}{|c|}{ Unstandardized Coefficients } & \multirow{2}{*}{$\begin{array}{l}\text { Standardized Coefficients } \\
\text { Beta }\end{array}$} & \multirow[t]{2}{*}{$\mathbf{T}$} & \multirow[t]{2}{*}{ Sig. } \\
\hline & & $\mathbf{B}$ & Std. Error & & & \\
\hline \multirow[t]{9}{*}{1} & (Constant) &,- 070 &, 054 & & $-1,294$ & ,204 \\
\hline & $\mathrm{CR}$ & 076 &, 026 & ,340 & 2,951 &, 005 \\
\hline & TAT & 005 &, 002 &, 310 & 2,660 & ,011 \\
\hline & DER &,- 008 &, 003 &,- 304 & $-2,397$ &, 022 \\
\hline & ROI & 016 &, 007 &, 285 & 2,256 &, 030 \\
\hline & $|\mathrm{CR}-\mathrm{EPS}|$ & ,001 & ,012 & $-13,893$ & ,107 & ,916 \\
\hline & $\mid$ TAT-EPS $\mid$ &,- 007 &, 002 & 22,636 & $-3,180$ &, 003 \\
\hline & $\mid$ DER-EPS $\mid$ & 011 &, 004 & $-8,656$ & 2,737 &, 009 \\
\hline & $\mid$ ROI-EPS $\mid$ &,- 005 & ,009 & 2,507 &,- 568 &, 573 \\
\hline
\end{tabular}

Based on the results of the study, it shows that the current ratio (CR) has a positive and significant effect on stock returns at Banking Companies on the Indonesia Stock Exchange. Total asset turnover (TAT) has a positive and significant effect on stock returns in Banking Companies on the Indonesia Stock Exchange. Debt to equity ratio (DER) has a negative and significant effect on stock returns of Banking Companies on the Indonesia Stock Exchange. Return on investment (ROI) has a positive and significant effect on stock returns of Banking Companies on the Indonesia Stock Exchange. Earning per share (EPS) is not able to significantly moderate the relationship between CR and stock returns. EPS is able to significantly moderate the relationship between TAT and stock returns. EPS is able to significantly moderate the relationship between DER and stock returns. EPS is not able to significantly moderate the relationship between ROI and stock returns.

\section{CONCLUSION AND SUGGESTION}

Based on the results of the study, it shows that the current ratio (CR) has a positive and significant effect on stock returns at Banking Companies on the Indonesia Stock Exchange. Total asset turnover (TAT) has a positive and significant effect on stock returns in Banking Companies on the Indonesia Stock Exchange. Debt to equity ratio (DER) has a negative and significant effect on stock returns of Banking Companies on the Indonesia Stock Exchange. Return on investment (ROI) has a positive and significant effect on stock returns of Banking Companies on the Indonesia Stock Exchange. Earning per share (EPS) is not able to significantly moderate the relationship between CR and stock returns. EPS is able to significantly moderate the relationship between TAT and stock returns. EPS is able to significantly moderate the relationship between DER and stock returns. EPS is not able to significantly moderate the relationship between ROI and stock returns. 
Sahat M N Siahaan et.al. Effect of financial ratios on stock returns with earning per share as moderating variable in banking companies on the Indonesia stock exchange (2012-2017 period).

The following are some suggestions from the author for researchers who want to continue research related to this research:

1. This research can be developed using other fundamental factors such as liquidity ratios, profitability ratios and macroeconomic factors such as inflation, exchange rates, interest rates, money supply and so on as predictors of stock returns.

2. For potential investors who want to invest in stocks, they should be able to consider the current ratio (CR), total asset turnover (TAT), debt to equity ratio (DER) and return on investment (ROI) factors because these factors have long-term effects. as well as in the short term on stock returns of industrial companies listed on the Indonesia Stock Exchange in 2012-2017.

3. For further researchers, it is better to extend the research period and increase the number of other companies listed on the Indonesia Stock Exchange (IDX). Because the more samples and populations taken will improve the quality of research and its results.

Acknowledgement: None

\section{Conflict of Interest: None}

\section{Source of Funding: None}

\section{REFERENCES}

1. Alwi, Z. I. (2010). Pasar Modal Teori dan Aplikasi. Jakarta: Yayasan Pancur Siwah.

2. Darmadji, T. \& H. M. Fakhruddin. (2011). Pasar Modal di Indonesia. Edisi 3. Jakarta: Salemba Empat.

3. Habib, Azwar. (2016). Pengaruh Faktor Fundamental dan Risiko Sistematik terhadap Return Saham Perusahaan Sektor Property di Bursa Efek. Skripsi. Fakultas Ekonomi, Universitas Negeri Yogyakarta.
4. Hermuningsih, Sri. (2012). Pengantar Pasar Modal Indonesia. Yogyakarta: UPPSTIM YKPN.

5. Kumala. (2013). Pengaruh Karkteristik dan Kompensasi Dewan Direksi terhadap Agresivitas Pajak (Studi pada Perusahaan Sektor Perdagangan, Jasa dan Investasi yang Terdaftar di Bursa Efek Indonesia Periode 2013-2017).

6. Pandiangan, Saut Maruli Tua, Rujiman, Rahmanta, Tanjung, Indra I., Darus, Muhammad Dhio, \& Ismawan, Agus. (2018).

7. An Analysis on the Factors which Influence Offering the Elderly as Workers in Medan. IOSR Journal of Humanities and Social Science (IOSR-JHSS), 23(10), 76-79. DOI: 10.9790/0837-2310087679.

http://www.iosrjournals.org/iosrjhss/papers/Vol.\%2023\%20Issue10/Version -8/K2310087679.pdf.

8. Petcharabul, Pinradee \& Suppanunta Romprasert. (2014). Technology Industry on Financial Ratios and Stock Returns. Journal of Business and Economics, 5(5), 739-746.

9. Prastowo, Dwi D. \& Rifka Juliaty. (2008). Analisis Laporan Keuangan: Konsep dan Aplikasi. Edisi Kedua. Yogyakarta: UPP STIM YKPN.

10. Rahman, Y. Abdul. (2014). The Art of RF (Riba Free) Islamic Banking and Finance: Tools and Tecniques for Coomunity-Based Banking. New Jersey: John Wiley \& Sons.

11. Tandelilin, E. (2010). Portofolio dan Investasi Teori dan Aplikasi. Edisi Pertama. Yogyakarta: Kanisius.

How to cite this article: Sahat M N Siahaan, Sadalia I, Silalahi AS. Effect of financial ratios on stock returns with earning per share as moderating variable in banking companies on the Indonesia stock exchange (2012-2017 period). International Journal of Research and Review. 2021; 8(8): 398-406. DOI: https://doi. org/10.52403/ijrr.20210855 